\title{
Preferences for redistribution in Europe
}

Correspondence: javier.olivera@uni.lu Institute for Research on Socio-Economic Inequality (IRSEI), Research Unit INSIDE, University of Luxembourg, Route de Diekirch, L-7220 Walferdange, Luxembourg

\section{Springer}

\begin{abstract}
This paper uses pseudo panel techniques and a fixed effects estimator to analyse the determinants of preferences for redistribution in 34 European countries over the period 2002-2012. The data is drawn from the six available waves of the European Social Survey. The main result is that changes in income inequality positively affect changes in preferences for redistribution over time. Though this result is predicted by standard political economy models, it has found little previous empirical support. This study shows that, at least in Europe, growing income inequality leads to more individual support for redistribution. The empirical results hold after performing a variety of robustness checks regarding the construction of pseudo panels, the use of lags and different measures of income inequality.

JEL codes: D31; D63; D72; H2O

Keywords: Redistribution; Income Inequality; Preferences for redistribution; Pseudo panels
\end{abstract}

\section{Introduction}

A common topic of interest for economists and other social scientists is the formation of preferences over how much income redistribution must be implemented, if any. As pointed by Alesina and Giuliano (2011), this is the most important dividing line between left and right political views concerning economic issues. Through political voting, these preferences can play a significant role in the final level of redistribution accomplished by the government. Early models of voting (Meltzer and Richard 1981) show that the median voter is decisive in pushing for redistribution when the median income is placed left of the mean income, i.e., when the income is unequally distributed. Although this model is insightful, there are missing mechanisms that, if accounted for, will produce different results. For example, individuals belonging to the lower part of the income distribution may have the expectation of upward mobility so that they will prefer less redistribution (Piketty 1995; Benabou and Ok 2001). Alesina and Angeletos (2005) show that societies where individual effort is believed to be the main source of income formation will prefer less taxes and redistribution. The contrary holds for societies that believe luck is important to create income, so they will prefer more redistribution. Furthermore, Karabarbounis (2011) finds empirical support for the 'one dollar, one vote' equilibrium, which means that richer groups of individuals are able to put forward their agenda on less taxes and redistribution through their economic and political influence.

(C) 2015 Olivera. This is an Open Access article distributed under the terms of the Creative Commons Attribution License (http:// creativecommons.org/licenses/by/4.0), which permits unrestricted use, distribution, and reproduction in any medium, provided the original work is properly credited. 
There are a number of studies analysing the determinants of preferences for redistribution, mainly exploiting the cross-country variation ${ }^{1}$. Although all these works are important in the literature of preferences for redistribution, they do not directly address the determinants of changes in these preferences. One of the reasons of this deficiency is the scarcity of adequate data for this purpose, i.e., panel data surveys that include questions on redistributive preferences.

The aim of this paper is to study the determinants of preferences for redistribution in Europe taking into account variation over time and country. Within this framework, particular attention is paid to the effects of income inequality on these preferences. In this way, this study attempts to discern whether growing income inequality, as is widely observed, has an effect on the formation of preferences for redistribution. It is important to mention that this study does not deal with the realisation of these preferences, i.e., this study does not analyse whether the actual degree of redistribution observed in a country corresponds to the realisation of the preferences for redistribution of its citizens. For such analysis, one would need to use a longer period of observations in order to account for political and economic cycles (like the study by Georgiadis and Manning (2012) for the UK). The present paper differs from the existing empirical literature in several respects. It uses a harmonised dataset composed of the total six waves of the European Social Survey (ESS) carried out between 2002 and 2012, which comprises a total of 34 countries and 235,842 individuals with non-missing information. This data is collapsed to construct synthetic panels based on birth year cohorts, sex and country in order to use pseudo panel techniques (Deaton 1985) and study the changes in inequality and preferences more fully. For this purpose, a fixed effects estimator is used. This strategy allows for overcoming the data limitations and assess the role of changing inequality on redistributive preferences. Furthermore, the analysis considers that individuals are not only influenced by the level of income inequality-as measured, for example, by the Gini coefficient or the top $1 \%$ income share-but also by the degree of redistribution which is already taking place in the country. In all these cases, the analyses use comparable and harmonised country level variables that vary over time.

The results indicate that variations in income inequality over time affect preferences for redistribution. These findings are robust to different measures of income inequality and specifications with different sizes and numbers of synthetic panels, and therefore the results provide evidence that preferences for redistribution are not immobile and that their evolution is influenced by changing income inequality. The positive effect of the Gini index computed with gross incomes (before tax and transfers) is particularly relevant for preferences for redistribution because this index is less influenced by the contemporaneous tax and transfer system. In addition, it is found that the level of actual redistribution operates in the opposite direction of income inequality, which helps to explain why some welfarist-oriented countries such as Denmark, Norway and Sweden exhibit a lower preference for redistribution. This can be interpreted as individuals living in economies where substantial redistribution already exists and do not want more redistribution. It is important to bear in mind that all these findings must be interpreted as short-time responses given the limited length of time of the data.

The paper is organised as follows. The next section briefly discuss the relevant literature. The third section presents the data. The fourth section presents the empirical 
strategy. Section 5 presents and discusses the econometric results, and section 6 concludes.

\section{The study of preferences for redistribution}

The main prediction of the median voter theorem (Meltzer and Richard 1981) is that the level of income inequality positively affects the size of income redistribution in the country. This result has led to the emergence of an important body of empirical studies trying to test its validity. This literature can be roughly subdivided into two branches: one branch uses measures of income inequality and redistribution (mostly the Gini coefficient and the ratio of median to mean income) at the country or state level. The other branch uses individual preferences for redistribution. In the first group of studies, the effect of inequality on redistribution has not received significant empirical support. Examples are Rodriguez (1999), Persson and Tabellini (1994), Perotti (1996), Moene and Wallerstein (2001, 2003), Lind (2005) and Shelton (2007). Exceptions are Milanovic (2000, 2010) and Karabarbounis (2011). The studies of the second branch attempt to uncover the determinants of individual preferences for redistribution, and some of these evaluate the effects of income inequality on redistributive preferences (see a summary in Table 1). Examples of studies assessing the role of economic inequality on redistributive preferences are Pittau et al. (2013), Kerr (2014), Tóth and Keller (2011), Yamamura (2012) and Jaeger (2013). The results of the effect of inequality on the preferences for redistribution are mixed, although a majority of them find a positive effect. The analysis is mainly based on cross-country differences so that the problems of unobserved effects and reverse causality come with caution when interpreting the results. However, Kerr (2014) uses an IV model to detect a positive effect of inequality on the demand for redistributions across American states, and Jaeger (2013) uses a pseudo panel approach. This last study, however, has three problems that affect the correct estimation and interpretation of the effect of income inequality on preferences for redistribution. The first one is the use of synthetic panels that are constructed on the base of variables (social class position) that are not immobile over time and not observable for all individuals ${ }^{2}$, which is a condition to build proper pseudo panels (Verbeek 2008). The second problem is the use of Gini indexes from seven different data sources for different countries, and even for the same country observed in different years ${ }^{3}$. This mix of sources and years severely limits the comparability of income inequality within and across countries and over time. Furthermore, the year of some Gini indexes does not correspond with the year of the ESS wave. The use of household income, without any adjustment, is also problematic as the ESS does not have a uniform income question across waves ${ }^{4}$.

Other approaches employed to understand how redistributive preferences are shaped pay particular attention to the formation of beliefs about income position, informational limitations on inequality levels and the influence of reference groups. These studies mostly use experiments as the empirical strategy to deal with the demanding set of required variables. Relevant examples are Kuziemko et al. (2013) and Cruces et al. (2013). Furthermore, a recent effort aimed at integrating the many findings and approaches in the formation of redistributive preferences is presented in Schokkaert and Truyts (2014) in the form of a model that considers the possibility of assessing 
Table 1 Literature on preferences for redistribution

\begin{tabular}{|c|c|c|c|c|}
\hline Study & Dataset & Region & Modelling & Effect of inequality \\
\hline \multirow[t]{2}{*}{ Pittau et al. (2013) } & ESS 2002-2008 & 23 EU countries & \multirow{2}{*}{$\begin{array}{l}\text { Logit } \\
\text { multilevel }\end{array}$} & + \\
\hline & GSS 2000-2006 & US states & & - \\
\hline \multirow[t]{3}{*}{ Kerr (2014) } & GSS 1972 -2000 & US (states) & OLS & + or insignificant \\
\hline & ISSP 1987, 92, 99 & \multirow[t]{2}{*}{ Many countries } & \multirow[t]{2}{*}{ IV OLS } & \\
\hline & WVS 1990, 95, 00 & & & \\
\hline $\begin{array}{l}\text { Tóth and Keller } \\
\text { (2011) }\end{array}$ & Eurobarometer 1999 & EU-27 & $\begin{array}{l}\text { OLS } \\
\text { Multilevel }\end{array}$ & + \\
\hline Yamamura (2012) & JGSS 2000-2008 & Japan & $\begin{array}{l}\text { Ordered } \\
\text { Probit }\end{array}$ & $\begin{array}{l}\text { + for high-income earners, } \\
\text { otherwise insignificant }\end{array}$ \\
\hline Jaeger (2013) & ESS 2002-2008 & 31 EU countries & $\begin{array}{l}\text { FE Pseudo } \\
\text { Panels }\end{array}$ & insignificant \\
\hline $\begin{array}{l}\text { Luttmer and } \\
\text { Singhal (2011) }\end{array}$ & ESS 2002-2006 & $32 \mathrm{EU}$ countries & OLS & Not studied \\
\hline Guillaud (2013) & ISSP 2006 & 33 countries & $\begin{array}{l}\text { Ordered } \\
\text { Logit }\end{array}$ & Not studied \\
\hline \multirow{2}{*}{$\begin{array}{l}\text { Alesina and } \\
\text { Giuliano (2011) }\end{array}$} & GSS 1972-2004 & US & \multirow[t]{2}{*}{ OLS } & \multirow[t]{2}{*}{ Not studied } \\
\hline & WV 1981, 90, 95, 99 & Many others & & \\
\hline $\begin{array}{l}\text { Alesina and Fuchs- } \\
\text { Schundeln (2007) }\end{array}$ & Panel GSOEP 1997-2002 & Germany & Probit & Not studied \\
\hline $\begin{array}{l}\text { Georgiadis and } \\
\text { Manning (2012) }\end{array}$ & BSAS & UK & OLS & Not studied \\
\hline $\begin{array}{l}\text { Alesina and La } \\
\text { Ferrara (2005) }\end{array}$ & GSS 1978-91 & US & $\begin{array}{l}\text { Ordered } \\
\text { Probit }\end{array}$ & Not studied \\
\hline $\begin{array}{l}\text { Corneo and } \\
\text { Grüner (2002) }\end{array}$ & ISSP 1992 & $\begin{array}{l}12 \text { developed } \\
\text { countries }\end{array}$ & Logit & Not studied \\
\hline Fong (2001) & $\begin{array}{l}\text { Gallup Poll Social Audit } \\
\text { Survey } 1998\end{array}$ & US & $\begin{array}{l}\text { Ordered } \\
\text { Probit }\end{array}$ & Not studied \\
\hline
\end{tabular}

Acronyms:

ESS: European Social Survey

GSOEP: German Socio Economic Panel

ISSP: International Social Survey Program

GSS: General Social Survey

WVS: World Values Survey

JGSS: Japanese General Social Survey

BSAS: British Social attitudes Survey

income differences caused by ability as unjust. This model is built on the premise that income differences caused by luck are seen as illegitimate, while those arising from effort are legitimate, and considers a utility function composed by a self-interested and a social justice part. It is shown that the desired degree of redistribution of an individual depends on the relative importance of luck, effort and ability assigned to explain income differences in an environment of informational bias originating from the reference group. This model also helps to understand recent experimental research finding that better-off individuals are more prone than poorer individuals to recognise other's effort when making allocations (Barr et al. 2015).

\section{Data and variables}

\subsection{The data}

The data is drawn from the complete set of available bi-annual rounds (six rounds) of the European Social Survey (ESS) from 2002 to 2012. This survey is designed to 
measure attitudes, beliefs, values and behaviour patterns of individuals in Europe. There is a core set of questions implemented in each wave and additional modules in specific waves. Income inequality measures are drawn from the Standardized World Income Inequality Database (SWIID version 4.0) because this data-although not without its problems-provides the broadest coverage across countries over time, allowing for the attainment of the largest number of country-year points, whereas data on income inequality from Eurostat covers fewer observations ${ }^{5}$. The SWIID provides Gini indexes computed with incomes both before and after taxes and transfers, and the top 1\% of share. While the Gini index captures inequality along the total distribution of incomes, the top income share is useful to capture income concentration at the very top of the income distribution. These measures cover different forms of income inequality and therefore make this study more complete. Given the recent revival of the importance of top incomes (Atkinson et al. 2011), the share of the top 1\% of the income distribution is considered as an additional measure of inequality in the analysis. Pittau et al. (2013) also use data from a previous version of SWIID to analyse preferences for redistribution, although they do not use the variation of inequality indices over time. The other macro variables used in the present analysis are the real and PPP-adjusted GDP per capita from the World Bank's World Development Indicators and public social protection expenditures (as percentage of GDP) from Eurostat. A total of 235,842 individuals have complete information for the variables of interest. This selection comprises a total of 34 countries and represents 152 country-year points. The included countries are the EU-28 (except Malta) plus Norway, Iceland, Russia, Switzerland, Turkey, Ukraine and Israel.

Not all countries have observations in each wave (see Table 2). There are 15 countries with observations in all 6 waves: Belgium, Denmark, Finland, Germany, Hungary, Ireland, the Netherlands, Norway, Poland, Portugal, Switzerland, Slovenia, Spain, Sweden and the United Kingdom. Furthermore, 3 countries have information in 5 waves: Czech Republic, Estonia and Slovakia. Austria, Bulgaria, Cyprus, France, Greece, the Russian Federation and Ukraine have observations in 4 waves. Israel, Italy and Lithuania are observed in 3 waves. Latvia and Romania are only observed in one period.

\subsection{The dependent variable}

The key question measuring individual preferences for redistribution is repeated in each wave, which is: "To what extent do you agree or disagree with the statement: the government should take measures to reduce differences in income levels". The individual must choose one of five responses, which are rescaled in the following way: strongly agree (5); agree (4); neither agrees nor disagree (3); disagree (2) and strongly disagree (1). Therefore, the higher this number, the more it favours redistribution. The average score of preference for redistribution is increasing across waves, though there are important differences among countries and years. For example, for those countries with observations in 2002 and 2012, the score increased in 14 countries and decreased in 3. The measures of inequality also show variation among countries and years. Between 2002 and 2012, the Gini of net incomes increased in 11 countries and decreased in 6 . The average increase is $5.7 \%$ and the average decrease is $-5.8 \%$. For the same period, the Gini of market incomes increased in 10 countries and decreased in 7, with 6.9\% 
Table 2 Composition of sample

\begin{tabular}{|c|c|c|c|c|c|c|c|}
\hline Total & 2012 & 2010 & 2008 & 2006 & 2004 & 2002 & Year \\
\hline 4 & & & $x$ & $x$ & $x$ & $x$ & Austria \\
\hline 6 & $x$ & $x$ & $x$ & $x$ & $x$ & $x$ & Belgium \\
\hline 4 & $x$ & $x$ & $x$ & $x$ & & & Bulgaria \\
\hline 2 & & $x$ & $x$ & & & & Croatia \\
\hline 4 & $x$ & $x$ & $x$ & $x$ & & & Cyprus \\
\hline 5 & $x$ & $x$ & $x$ & & $x$ & $x$ & Czech Rep \\
\hline 6 & $x$ & $x$ & $x$ & $x$ & $x$ & $x$ & Denmark \\
\hline 5 & $x$ & $x$ & $x$ & $x$ & $x$ & & Estonia \\
\hline 6 & $x$ & $x$ & $x$ & $x$ & $x$ & $x$ & Finland \\
\hline 4 & $x$ & $x$ & $x$ & $x$ & & & France \\
\hline 6 & $x$ & $x$ & $x$ & $x$ & $x$ & $x$ & Germany \\
\hline 4 & & $x$ & $x$ & & $x$ & $x$ & Greece \\
\hline 6 & $x$ & $x$ & $x$ & $x$ & $x$ & $x$ & Hungary \\
\hline 2 & $x$ & & & & $x$ & & Iceland \\
\hline 6 & $x$ & $x$ & $x$ & $x$ & $x$ & $x$ & Ireland \\
\hline 3 & & $x$ & $x$ & & & $x$ & Israel \\
\hline 3 & $x$ & & & & $x$ & $x$ & Italy \\
\hline 1 & & & $x$ & & & & Latvia \\
\hline 3 & $x$ & $x$ & $x$ & & & & Lithuania \\
\hline 2 & & & & & $x$ & $x$ & Luxembourg \\
\hline 6 & $x$ & $x$ & $x$ & $x$ & $x$ & $x$ & Netherlands \\
\hline 6 & $x$ & $x$ & $x$ & $x$ & $x$ & $x$ & Norway \\
\hline 6 & $x$ & $x$ & $x$ & $x$ & $x$ & $x$ & Poland \\
\hline 6 & $x$ & $x$ & $x$ & $x$ & $x$ & $x$ & Portugal \\
\hline 1 & & & $x$ & & & & Romania \\
\hline 4 & $x$ & $x$ & $x$ & $x$ & & & Russian Fed \\
\hline 5 & $x$ & $x$ & $x$ & $x$ & $x$ & & Slovakia \\
\hline 6 & $x$ & $x$ & $x$ & $x$ & $x$ & $x$ & Slovenia \\
\hline 6 & $x$ & $x$ & $x$ & $x$ & $x$ & $x$ & Spain \\
\hline 6 & $x$ & $x$ & $x$ & $x$ & $x$ & $x$ & Sweden \\
\hline 6 & $x$ & $x$ & $x$ & $x$ & $x$ & $x$ & Switzerland \\
\hline 2 & & & $x$ & & $x$ & & Turkey \\
\hline 4 & & $x$ & $x$ & $x$ & $x$ & & Ukraine \\
\hline 6 & $x$ & $x$ & $x$ & $x$ & $x$ & $x$ & UK \\
\hline 152 & & & & & & & Total \\
\hline
\end{tabular}

being the average increase and $-5.8 \%$ the average decrease. In the case of the top $1 \%$ of income share, this has increased in 12 countries and declined in 5 countries.

The data shows a great deal of variability across countries and over time in redistributive preferences. The mean score for the variable measuring preferences for redistribution (from 1 to 5 ) in the complete 2002-2012 period is 3.84. The countries with the highest and lowest scores are Greece with 4.35 and Denmark with 3.03, respectively. Confirming some regional differences, the Mediterranean countries are placed well 
above the Nordic countries (see Figure 1). The relation between preferences for redistribution and income inequality is positive when attention is paid to cross-country differences, which is reported in the left-hand panel of Figure 2. At first glance, it is surprising that traditional pro-welfare states like the Nordic countries have simultaneously low levels of inequality and lower preferences for redistribution. However, it is possible that individuals who in general are in favour of income redistribution are less willing to favour more redistribution if the scale of redistribution already taking place is high enough. An indication of this can be observed in the right hand panel of Figure 2. The share of public social protection expenditures to GDP may be interpreted as a rough measure of the size of redistribution implemented in the country. The figure suggests some tendency for preferences for redistribution to be lower where the size of redistribution to GDP is higher.

\subsection{The control variables}

The variables used in the regression analysis are the standard individual controls employed in the literature of redistributive preferences and include sex, age, marital status (living with partner), education level in the form ISCED dummies, belonging to a minority ethnic group in the country (ethnic), and the religious position of the individual regardless of any particular religion (religious) in a scale from 1 (not at all) to 10 (very religious). The ESS has no uniform question on household income, but an income proxy that is asked in every wave is included. This is "which of the descriptions on this card comes closest to how you feel about your household's income nowadays?" with four possible scales: living comfortably on present income (1), coping on present income (2), difficult on present income (3) and very difficult on present income (4). Of course, this question may refer to satisfaction with income, so one should be cautious in interpreting the estimates of this variable. Another group of control variables refers to labour conditions of the individual and includes the dummy variables retired and unemployed. Finally, left-right political scale denotes the self-placement of the individual in the political spectrum from 0 (left) to 10 (right). The descriptive statistics of the variables are reported in Table 3.

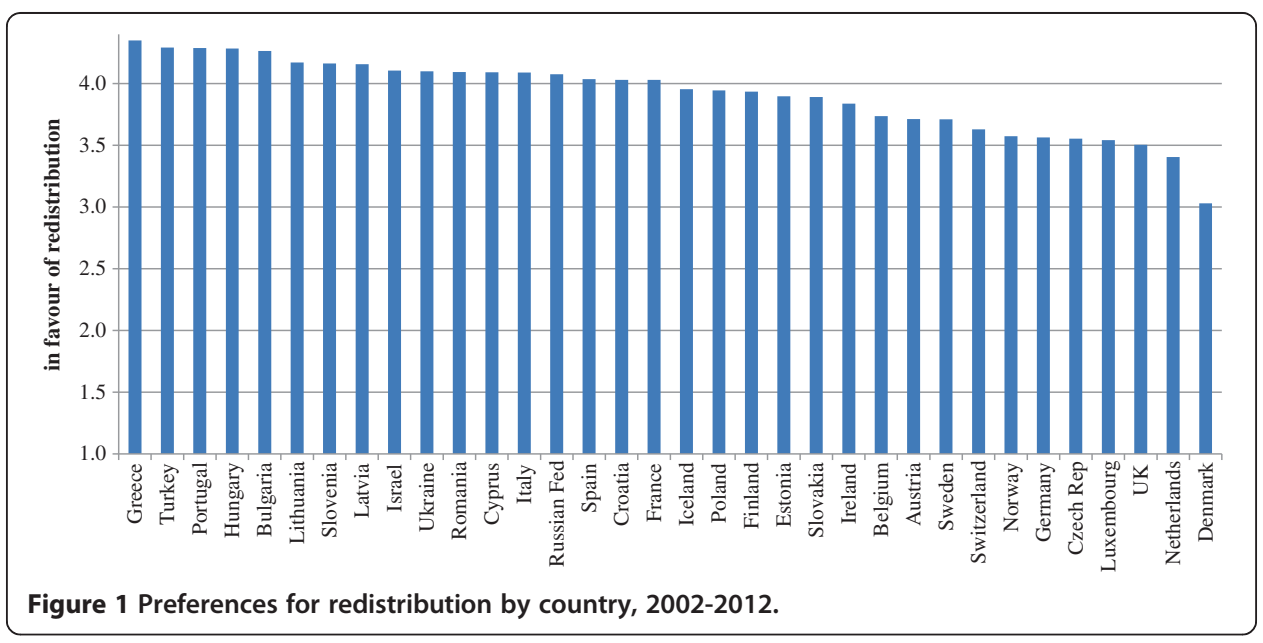



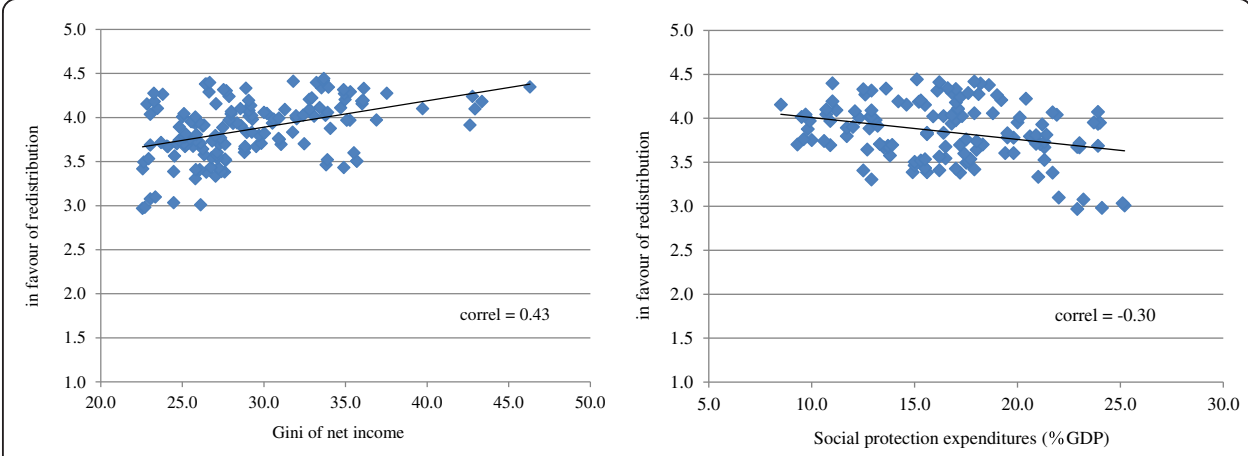

Figure 2 Preferences for redistribution and income inequality, 2002-2012.

\section{Empirical strategy}

In the empirical literature of preferences for redistribution, it is a common practice to use the multi-scale variable of preferences for redistribution and estimate with OLS. Examples of this are Georgiadis and Manning (2012), Kerr (2014), Alesina and Giuliano (2011) and Luttmer and Singhal (2011). All of them argue that the use of alternative modelling approaches such as the ordered logit model do not change the results. Differently, Pittau et al. (2013) recode the original 5-scale question on preferences for redistribution into $1 / 0$ and apply a logistic regression with multi-level modelling. Guillaud (2013) use an ordered logit and Alesina and La Ferrara (2005) use ordered probit and probit models. Even though the specification models of some of these studies have controlled for country and time effects with dummy variables, one cannot fully assure that changes in income inequality and redistribution over time have the same effects over the preferences for redistribution. Panel data can help to study the effects of income inequality over time because the reaction of the same unit of analysis to changing inequality can be followed across time. The application of a fixed effects model will allow for controlling for time-invariant observed and unobserved effects. This is an essential distinction with respect to pooled OLS models (such as Kerr 2014; Luttmer and Singhal 2011; Alesina and Giuliano 2011; and Alesina and La Ferrara 2005) because the differences in the preferences for redistribution may vary irrespective of the differences in income inequality across countries. In that case, the difference in the preference for redistribution will be more related to specific and persistent factors of the country that shape the preferences of their citizens. For example, Karabarbounis (2011) cite legal origins, political institutions, persistent cultural characteristics, ethnic fragmentation, prospects of upward mobility, and social beliefs about fairness. Country differences in culture (Berigan and Irwin 2011) and national identity (Shayo 2009) are also part of those specific factors that can affect the demand for redistribution. In a panel data structure with $i=1, \ldots N$ individuals followed across $\mathrm{t}=1, \ldots, T$ periods, it is common to use the following specification:

$$
y_{i t}=\delta_{t}+\alpha_{i}+\beta X_{i t}+\gamma Z_{i t}+\mu_{i t}
$$

The dependent variable $y_{i t}$ measures the individual preference for redistribution in year $t$. The vector $X_{i t}$ contains inequality measures that are the same for individuals of the same country and year. $Z_{i t}$ denotes individual and time specific socio-demographic variables. The term $\alpha_{i}$ is the year-invariant individual unobserved effect; $\delta_{t}$ is a common 


\begin{tabular}{|c|c|c|c|c|c|c|c|c|c|c|c|c|c|c|}
\hline Variable & 2002 & & 2004 & & 2006 & & 2008 & & 2010 & & 2012 & & Total & \\
\hline & mean & sd & mean & sd & mean & sd & mean & sd & mean & sd & mean & sd & mean & sd \\
\hline in favour of redistribution & 3.74 & 1.06 & 3.79 & 1.06 & 3.83 & 1.05 & 3.84 & 1.04 & 3.92 & 1.04 & 3.90 & 1.03 & 3.84 & 1.05 \\
\hline gini net incomes & 28.24 & 4.05 & 28.98 & 5.08 & 28.55 & 4.07 & 30.12 & 5.06 & 29.69 & 4.69 & 29.53 & 4.58 & 29.26 & 4.69 \\
\hline gini market incomes & 41.70 & 4.12 & 41.87 & 4.57 & 42.12 & 5.21 & 42.44 & 5.49 & 42.15 & 5.63 & 43.01 & 5.13 & 42.24 & 5.11 \\
\hline top $1 \%$ income share & 8.26 & 2.30 & 8.09 & 2.10 & 8.70 & 3.03 & 8.89 & 2.64 & 8.56 & 2.45 & 8.55 & 2.27 & 8.53 & 2.50 \\
\hline $\log g d p p c$ & 10.22 & 0.34 & 10.12 & 0.50 & 10.14 & 0.47 & 10.11 & 0.44 & 10.09 & 0.42 & 10.19 & 0.34 & 10.14 & 0.43 \\
\hline social protection expend. & 17.14 & 3.62 & 17.08 & 4.09 & 17.04 & 3.97 & 15.32 & 4.01 & 18.04 & 3.60 & 17.45 & 3.80 & 16.97 & 3.96 \\
\hline left-right political scale & 5.12 & 2.17 & 5.16 & 2.18 & 5.08 & 2.16 & 5.19 & 2.25 & 5.18 & 2.17 & 5.17 & 2.22 & 5.16 & 2.20 \\
\hline male & 0.50 & 0.50 & 0.48 & 0.50 & 0.49 & 0.50 & 0.48 & 0.50 & 0.48 & 0.50 & 0.48 & 0.50 & 0.48 & 0.50 \\
\hline living with partner & 0.65 & 0.48 & 0.64 & 0.48 & 0.65 & 0.48 & 0.64 & 0.48 & 0.63 & 0.48 & 0.63 & 0.48 & 0.64 & 0.48 \\
\hline age & 45.50 & 17.47 & 45.62 & 17.67 & 46.55 & 17.86 & 46.58 & 17.81 & 47.63 & 18.10 & 48.10 & 18.05 & 46.71 & 17.87 \\
\hline isced: 1 & 0.13 & 0.33 & 0.15 & 0.36 & 0.11 & 0.32 & 0.11 & 0.32 & 0.11 & 0.31 & 0.09 & 0.29 & 0.12 & 0.32 \\
\hline isced: 2 & 0.22 & 0.41 & 0.19 & 0.39 & 0.18 & 0.39 & 0.17 & 0.37 & 0.14 & 0.35 & 0.15 & 0.36 & 0.17 & 0.38 \\
\hline isced: 3 & 0.40 & 0.49 & 0.40 & 0.49 & 0.39 & 0.49 & 0.40 & 0.49 & 0.40 & 0.49 & 0.39 & 0.49 & 0.40 & 0.49 \\
\hline isced: 4 & 0.02 & 0.13 & 0.02 & 0.16 & 0.03 & 0.17 & 0.03 & 0.16 & 0.05 & 0.22 & 0.05 & 0.22 & 0.03 & 0.18 \\
\hline isced: 5 & 0.23 & 0.42 & 0.23 & 0.42 & 0.28 & 0.45 & 0.29 & 0.45 & 0.30 & 0.46 & 0.31 & 0.46 & 0.28 & 0.45 \\
\hline isced: other & 0.00 & 0.04 & 0.00 & 0.06 & 0.00 & 0.03 & 0.00 & 0.02 & 0.00 & 0.04 & 0.00 & 0.05 & 0.00 & 0.04 \\
\hline income: living comfortably & 0.35 & 0.48 & 0.31 & 0.46 & 0.32 & 0.47 & 0.27 & 0.44 & 0.27 & 0.44 & 0.28 & 0.45 & 0.30 & 0.46 \\
\hline income: coping on & 0.46 & 0.50 & 0.45 & 0.50 & 0.45 & 0.50 & 0.45 & 0.50 & 0.44 & 0.50 & 0.45 & 0.50 & 0.45 & 0.50 \\
\hline income: difficult on & 0.15 & 0.36 & 0.18 & 0.38 & 0.17 & 0.37 & 0.21 & 0.40 & 0.20 & 0.40 & 0.19 & 0.39 & 0.19 & 0.39 \\
\hline income: very difficult on & 0.04 & 0.20 & 0.06 & 0.24 & 0.06 & 0.23 & 0.07 & 0.26 & 0.09 & 0.28 & 0.08 & 0.26 & 0.07 & 0.25 \\
\hline ethnic & 0.04 & 0.19 & 0.04 & 0.20 & 0.05 & 0.22 & 0.06 & 0.25 & 0.06 & 0.24 & 0.06 & 0.24 & 0.05 & 0.22 \\
\hline religious & 4.94 & 2.90 & 4.91 & 2.93 & 4.72 & 2.90 & 4.80 & 2.96 & 4.64 & 2.94 & 4.57 & 3.01 & 4.76 & 2.95 \\
\hline retired & 0.20 & 0.40 & 0.22 & 0.41 & 0.23 & 0.42 & 0.22 & 0.42 & 0.25 & 0.43 & 0.24 & 0.42 & 0.23 & 0.42 \\
\hline unemployed & 0.05 & 0.23 & 0.06 & 0.24 & 0.05 & 0.22 & 0.06 & 0.24 & 0.08 & 0.27 & 0.07 & 0.26 & 0.06 & 0.24 \\
\hline No. of observations & 33704 & & 37709 & & 34473 & & 48531 & & 41687 & & 39738 & & 235842 & \\
\hline No. of countries & 21 & & 25 & & 23 & & 31 & & 27 & & 25 & & 34 & \\
\hline
\end{tabular}


unobservable year-specific effect, and $\mu_{i t}$ is the time-varying individual specific idiosyncratic error. It is well established in the empirical literature that if $\alpha_{i}$ is not controlled for and instead is let to be part of the composite error, the estimators will be inconsistent. In particular, the inequality measures and other explanatory variables can be correlated with the unobserved individual effects so that without dealing with these effects, the estimation will suffer from omitted-variables problem. A fixed effect estimator (FE) will take away the individual unobserved effects by subtracting the time means of each variable for every individual in the model. The interesting point is that this procedure will allow the unobserved effect $\alpha_{i}$ to be arbitrarily correlated with the time-varying explanatory variables.

Unfortunately there is no panel survey to study preferences for redistribution in Europe, but one can construct a pseudo panel dataset (a practice initiated by Deaton 1985) with the ESS data. A pseudo panel dataset includes groups (generally individuals grouped in birth cohorts) that can be followed over time. The characteristics of these groups are built by averaging the individuals identified in each group. It is important that these groups can be identified by variables that do not change over time. For example, the year of birth, sex and countries are the usual identifiers. These groups are called synthetic or pseudo panels and will appear over time in different cross-sections of harmonised and comparable surveys. An important characteristic is that these crosssections must be random samples of the population, which is fulfilled by the ESS. The following specification is used for the collapsed dataset, where the sub-index $g$ indicates a particular synthetic panel and the hat indicates average:

$$
\bar{y}_{g t}=\delta_{t}+\alpha_{g}+\beta_{g} \bar{X}_{g t-1}+\gamma_{g} \bar{Z}_{g t}+\mu_{g t}
$$

The pseudo panels are formed on the basis of birth year cohorts $(10)^{6}$, sex (2), country (34) and ESS rounds (6) so that the maximum possible number of synthetic observations is $10 \times 2 \times 34 \times 6=4,080$. In Equation 2, the unobserved cohort effect $\alpha_{g}$ is the average of the unobserved effects over time, but it is standard to assume that this is time-invariant. If cohort averages are based on a large number of individuals, this is a reasonable assumption, and one can obtain consistent estimators with an FE model (Verbeek 2008). Another condition to obtain consistent estimators is that the cohort averages show genuine time variation. It should be a balance between the number and size of the cohorts. More cohorts will refrain from small sample problems in the estimators, but fewer individuals in each cohort will reduce the reliability of the averages taken in the cohort?

Table 4 reports the composition of the pseudo panels over time and by birth year. There are a total of 2,657 synthetic observations that summarise the information of 219,102 individuals. The synthetic observations that contained less than 30 respondents were removed because the averaged variables may not be a good estimate of the characteristics of the cohort. Furthermore, some countries and cohorts are not surveyed in all years, and hence the total number of panels is lower than the theoretical maximum of 4,080. The pseudo panel regressions of the next section will include fixed effects estimators based on Equation 2, use robust standard errors clustered by country and cohort and include year dummies to control for time effects. The time effects help to mitigate the effects of spurious trends and contemporaneous panel error correlations 
Table 4 Composition of the pseudo panels

\begin{tabular}{lcccccccc}
\hline Cohort & $\mathbf{2 0 0 2}$ & $\mathbf{2 0 0 4}$ & $\mathbf{2 0 0 6}$ & $\mathbf{2 0 0 8}$ & $\mathbf{2 0 1 0}$ & $\mathbf{2 0 1 2}$ & Total of pseudo panels & Total of respondents \\
\hline $1920-26$ & 26 & 16 & 13 & 6 & 1 & 0 & 62 & 2,554 \\
$1927-33$ & 41 & 39 & 39 & 39 & 34 & 20 & 212 & 10,841 \\
$1934-40$ & 42 & 47 & 46 & 59 & 52 & 45 & 291 & 19,546 \\
$1941-47$ & 42 & 47 & 46 & 62 & 54 & 47 & 298 & 24,758 \\
$1948-54$ & 42 & 49 & 46 & 62 & 53 & 50 & 302 & 28,734 \\
$1955-61$ & 42 & 49 & 46 & 62 & 54 & 50 & 303 & 29,665 \\
$1962-68$ & 42 & 49 & 46 & 62 & 54 & 50 & 303 & 30,025 \\
$1969-75$ & 42 & 48 & 46 & 62 & 54 & 49 & 301 & 27,890 \\
$1976-82$ & 41 & 48 & 45 & 62 & 53 & 50 & 299 & 24,804 \\
$1983-89$ & 32 & 47 & 42 & 62 & 53 & 50 & 286 & 20,285 \\
Total & 392 & 439 & 415 & 538 & 462 & 411 & 2,657 & 219,102 \\
\hline
\end{tabular}

(Karabarbounis 2011). Given the use of fixed effects estimators and panel data, the explanatory variables included in the regressions are only those that vary over time.

\section{Econometric results}

\subsection{Main results}

The coefficient of self-assessment of political ideology (from $0=$ left to $10=$ right) is significant and negative, i.e., leftists are more in favour of redistribution than right-wing individuals, which is also found in Alesina et al. (2004) and Alesina and Giuliano (2011). An increase in tertiary education (isced 5) leads to a decrease in the support for redistribution, but a raise in post-secondary education (isced 4) increases such support. The coefficient of age indicates that, when cohort effects are controlled, younger rather than older individuals are more in favour of redistribution. The proxy for family income indicates that income matters with the demand for redistribution. As other studies show, individuals with better incomes are less in favour of redistribution, which support the hypothesis of preferences governed by self-interest. Note, however, that the only category of income with statistical significance is the one that indicates the best income (income nowadays: living comfortably). Religiosity, irrespective of any particular religion, has a positive effect on the redistributive preferences. Pittau et al. (2013) note that this result may indicate a relationship between the altruism underlying some religions and the preferences to distribute to the less advantaged. None of the controls related to the labour market matter on individual preferences for redistribution.

The results reported in columns $1-3$ of Table 5 indicate that an increase in any of the measures of income inequality can raise preferences for redistribution over time. For example, an additional percentage point in Gini net and Gini market increases the preferences for redistribution by $0.25 \%$ and $0.16 \%$, respectively, evaluated at sample means. It is notable that all the coefficients of these inequality indices are positive and statistically significant because each index of income inequality involves different concepts of inequality. Gini net measures inequality of disposable income (income after transfers and taxes) so that this indicator considers taxation and redistributive policies in the country. Gini market measures inequality of gross incomes, so that this indicator is less affected by taxation policies, but it is influenced by labour supply and general 
Table 5 Fixed effects estimates for preferences for redistribution

\begin{tabular}{|c|c|c|c|c|}
\hline Variables & (1) & (2) & (3) & (4) \\
\hline \multirow[t]{2}{*}{ gini net } & $0.0097^{* * *}$ & & & \\
\hline & $(0.0036)$ & & & \\
\hline \multirow[t]{2}{*}{ gini market } & & $0.0060^{* *}$ & & \\
\hline & & $(0.0023)$ & & \\
\hline \multirow[t]{2}{*}{ top $1 \%$ income share } & & & $0.0082^{* *}$ & \\
\hline & & & $(0.0037)$ & \\
\hline \multirow[t]{2}{*}{ social protection expenditures } & & & & $-0.0111^{* *}$ \\
\hline & & & & $(0.0047)$ \\
\hline \multirow[t]{2}{*}{$\log$ GDP pc } & 0.1328 & 0.1365 & 0.0979 & \\
\hline & $(0.0892)$ & $(0.0899)$ & $(0.0952)$ & \\
\hline \multirow[t]{2}{*}{ left-right political scale } & $-0.0849^{* * *}$ & $-0.0818^{* * *}$ & $-0.0802^{* * *}$ & $-0.0796^{* * *}$ \\
\hline & $(0.0131)$ & $(0.0129)$ & $(0.0128)$ & $(0.0150)$ \\
\hline \multirow[t]{2}{*}{ living with partner } & $0.0815^{*}$ & $0.0766^{*}$ & $0.0755^{*}$ & 0.0666 \\
\hline & $(0.0430)$ & $(0.0425)$ & $(0.0429)$ & $(0.0456)$ \\
\hline \multirow[t]{2}{*}{ age } & $-0.0325^{* * *}$ & $-0.0301^{* *}$ & $-0.0262^{* *}$ & $-0.0266^{* *}$ \\
\hline & $(0.0123)$ & $(0.0121)$ & $(0.0121)$ & $(0.0123)$ \\
\hline \multirow[t]{2}{*}{ education: isced 2} & 0.0311 & 0.0166 & 0.0154 & 0.0581 \\
\hline & $(0.0905)$ & $(0.0897)$ & $(0.0904)$ & $(0.0962)$ \\
\hline \multirow[t]{2}{*}{ education: isced 3} & -0.0184 & -0.0216 & -0.0083 & 0.0119 \\
\hline & $(0.0865)$ & $(0.0860)$ & $(0.0865)$ & $(0.0861)$ \\
\hline \multirow[t]{2}{*}{ education: isced 4} & $0.4296^{* * *}$ & $0.3687^{* * *}$ & $0.3832^{* * *}$ & $0.4711^{* * *}$ \\
\hline & $(0.1313)$ & $(0.1350)$ & $(0.1322)$ & $(0.1325)$ \\
\hline \multirow[t]{2}{*}{ education: isced 5} & $-0.1646^{*}$ & $-0.1643^{*}$ & $-0.1591^{*}$ & $-0.2009^{* *}$ \\
\hline & $(0.0865)$ & $(0.0866)$ & $(0.0871)$ & $(0.0891)$ \\
\hline \multirow[t]{2}{*}{ education: isced 6} & 0.4762 & 0.4484 & 0.5150 & 0.5370 \\
\hline & $(0.4879)$ & $(0.4876)$ & $(0.4893)$ & $(0.5023)$ \\
\hline \multirow[t]{2}{*}{ income nowadays: living comfortably } & $-0.2756^{* *}$ & $-0.2668^{* *}$ & $-0.2710^{* *}$ & $-0.3555^{* * *}$ \\
\hline & $(0.1169)$ & $(0.1185)$ & $(0.1180)$ & $(0.1253)$ \\
\hline \multirow[t]{2}{*}{ income nowadays: coping on } & -0.0707 & -0.0817 & -0.0736 & -0.1187 \\
\hline & $(0.1169)$ & $(0.1196)$ & $(0.1187)$ & $(0.1281)$ \\
\hline \multirow[t]{2}{*}{ income nowadays: difficult on } & -0.0138 & -0.0183 & -0.0317 & -0.1166 \\
\hline & $(0.1300)$ & $(0.1321)$ & $(0.1326)$ & $(0.1461)$ \\
\hline \multirow[t]{2}{*}{ ethnic } & -0.0471 & -0.0359 & -0.0256 & -0.0507 \\
\hline & $(0.1045)$ & $(0.1046)$ & $(0.1047)$ & $(0.1275)$ \\
\hline \multirow[t]{2}{*}{ religious } & $0.0251^{* *}$ & $0.0279^{* *}$ & $0.0260^{* *}$ & 0.0165 \\
\hline & $(0.0109)$ & $(0.0110)$ & $(0.0109)$ & $(0.0111)$ \\
\hline \multirow[t]{2}{*}{ retired } & 0.0711 & 0.0698 & 0.0658 & 0.0464 \\
\hline & $(0.0480)$ & $(0.0472)$ & $(0.0480)$ & $(0.0509)$ \\
\hline \multirow[t]{2}{*}{ unemployed } & -0.0586 & -0.0842 & -0.0832 & 0.0458 \\
\hline & $(0.1072)$ & $(0.1090)$ & $(0.1095)$ & $(0.1159)$ \\
\hline \multirow[t]{2}{*}{ constant } & $4.0381^{* * *}$ & $3.9139 * * *$ & $4.3020^{* * * *}$ & $5.6258^{* * *}$ \\
\hline & $(1.0176)$ & $(1.0120)$ & $(1.0485)$ & $(0.5989)$ \\
\hline Pseudo panels & 2657 & 2657 & 2657 & 2348 \\
\hline Adjusted $R^{2}$ & 0.180 & 0.180 & 0.179 & 0.161 \\
\hline
\end{tabular}

${ }^{* * *} p<0.01, * * p<0.05,{ }^{*} p<0.1$. Standard errors (in parenthesis) are robust and clustered by country and cohort. Each regression includes year dummies. The reference variable for income and education is "income nowadays: very difficult on" and "isced 1". 
equilibrium effects. The top 1\% income share is an index of income concentration that is receiving revitalised attention. The inequality measures are lagged one year because it is possible that synthetic individuals are not fully able to observe contemporaneous inequality but are in a better position to account for past inequality. Moreover, the results in column 4 of Table 5 indicate that the actual level of redistribution in the country (measured with the public social protection expenditures divided by GDP) reduces the demand for redistribution ${ }^{8}$. Overall, these results indicate that, in general, individuals may be in favour of redistribution when income inequality is high, but they can prefer less redistribution if the actual level of redistribution (measured with public social protection expenditures) in the country is already high. This can explain, as noted before, why some traditional welfare oriented countries, like Denmark, Norway and Sweden may have a lower preference for redistribution. Although employing another empirical strategy, Pittau et al. (2013) also find that social expenditures are negatively associated with the individual demand for redistribution in a hierarchical model where social expenditures do not vary over time.

The results are similar whether the inequality index employed in the regressions is lagged two years (Table 6's middle panel). Furthermore, the results do not differ whether the inequality index employed in the regressions corresponds to the average of the one-year and two-year lagged index (Table 6's bottom panel). For example, in 2012, Gini net would be the average of this indicator observed in years 2011 and 2010. This procedure reduces serial correlation and measurement error. Regarding the effects of income redistribution, it is found that the effect of public social protection expenditures on redistributive preferences is statistically significant and negative when this variable is lagged one year or is the average of one-year and two-year lags.

Table 6 FE coefficients of different inequality measures

\begin{tabular}{lllll}
\hline & coeff & std error & adj $R^{\mathbf{2}}$ & obs \\
\hline lagged one year: & & & & \\
gini net & $0.0097^{* * *}$ & $(0.0036)$ & 0.180 & 2657 \\
gini market & $0.0060^{* *}$ & $(0.0023)$ & 0.180 & 2657 \\
top 1\% income share & $0.0082^{* *}$ & $(0.0037)$ & 0.179 & 2657 \\
social protection expend, \% GDP & $-0.0111^{* *}$ & $(0.0047)$ & 0.161 & 2348 \\
lagged two years: & & & & \\
gini net & $0.0071^{* *}$ & $(0.0033)$ & 0.183 & 2657 \\
gini market & $0.0033^{*}$ & $(0.0018)$ & 0.182 & 2657 \\
top 1\% income share & $0.0196^{* * *}$ & $(0.0052)$ & 0.191 & 2657 \\
social protection expend, \% GDP & -0.0049 & $(0.0045)$ & 0.157 & 2329 \\
1 year lag $\times 2$ year lag: & & & & \\
gini net & $0.0088^{* *}$ & $(0.0035)$ & 0.181 & 2657 \\
gini market & $0.0047^{* *}$ & $(0.0021)$ & 0.181 & 2657 \\
top 1\% income share & $0.0137^{* * *}$ & $(0.0046)$ & 0.184 & 2657 \\
social protection expend, \% GDP & $-0.0091^{*}$ & $(0.0050)$ & 0.159 & 2348 \\
\hline
\end{tabular}

${ }^{* * *} \mathrm{p}<0.01,{ }^{* *} \mathrm{p}<0.05,{ }^{*} \mathrm{p}<0.1$. Standard errors are robust and clustered by country and cohort. Each row corresponds to a different regression and only reports the corresponding income inequality coefficient. Each regression includes the same covariates as in Table 5, and year dummies. In the first panel, inequality measures are lagged one year with respect to the ESS wave as in previous specifications. In the middle panel, inequality measures are lagged two years. In the bottom panel, the inequality measures are the averages of the one and two year lags. 
A possible concern related to the econometric modelling is the existence of reverse causality, meaning that the level of income inequality in a society depends on the preferences for redistribution of its members. This will be true if the government genuinely aligns its policies with the redistributive preferences of the individuals and sets up a taxation system that will cancel out any increase in pre-tax and transfer income inequality. However, it is difficult to establish that a change in redistributive preferences leads to a change in the taxation system at least in the short-run. Recall that the analysis employs bi-annual survey waves collected between 2002 and 2012, so the period may be too short to expect a relation running from preferences to inequality. In any case, it has been detected that pre-tax and pre-transfer income inequality positively and significantly affects the preferences for redistribution. As pointed out by Karabarbounis (2011), the use of pre-tax and transfer incomes instead of net incomes to construct the measure of inequality relaxes somewhat the reverse causation because net incomes vary automatically with the fiscal system, whilst pre-tax and transfer incomes vary only through the endogenous response of labour supply or the general equilibrium effects on factor prices. The same author uses lags of gross income inequality and their averages to mitigate the effects of redistribution on inequality through labour supply and general equilibrium effects. In addition, the top 1\% income share is also computed with pre-tax and transfer incomes so that this indicator also has the same desirable features of Gini market. As reported in Table 6, the results are robust with lags (and averages of lags) of pre-tax and transfer income inequality and top income shares.

\subsection{Checks}

Imposing a minimum size for the number of respondents in each synthetic panel can create some small sample problems. However, if no limits on the synthetic panel size is imposed, the econometric results are still very similar, and only the coefficient of the top $1 \%$ income share loses statistical significance. On the other hand, the sample size $\mathrm{n}=30$ for each synthetic panel can be considered to be too small and compromise the reliability of the averaged variables in each cell. But, the coefficients and their statistical significance practically do not change if a minimum of $n=50$ respondents is used instead of 30 for the size of the cells. Furthermore, the value of the adjusted $\mathrm{R}^{2}$ slightly decreases when no limit is imposed on the cell size and increases when the minimum size of each cell is 50. Another concern for the consistency of the pseudo panel estimators is the number of synthetic individuals. To check this, two alternative datasets were constructed by changing the birth year range of the cohorts to be spaced every 10 or 5 years instead of 7 . In the first case, there are 7 birth year cohorts producing a total of 1,963 synthetic observations with data. In the second case, there are 14 birth year cohorts and a total of 3,372 synthetic observations ${ }^{9}$. The results do not change substantively under both alternatives, and only the coefficient for the average of lagged years of social protection expenditures loses its statistical significance in the sample with 7 birth cohorts. Furthermore, in the sample with 7 birth cohorts, the adjusted $R^{2}$ improves slightly. All these results are summarised in Table 7 and reassure that inequality-measured with three different inequality indexes-positively affects the demand for redistribution. 
Table $7 \mathrm{FE}$ estimators with different sizes and numbers of synthetic individuals

\begin{tabular}{|c|c|c|c|c|c|c|c|c|c|c|c|c|c|c|c|c|c|c|c|c|}
\hline \multirow[t]{3}{*}{ Variable } & \multirow{2}{*}{\multicolumn{4}{|c|}{$\begin{array}{l}\text { Baseline: Cohort size } \geq 30 \\
\& 10 \text { birth year cohorts }\end{array}$}} & \multirow{2}{*}{\multicolumn{4}{|c|}{$\begin{array}{l}\text { Cohort size } \geq 50 \\
\& 10 \text { birth year cohorts }\end{array}$}} & \multirow{2}{*}{\multicolumn{4}{|c|}{$\begin{array}{l}\text { No minimum cohort size } \\
\& 10 \text { birth year cohorts }\end{array}$}} & \multirow{2}{*}{\multicolumn{4}{|c|}{$\begin{array}{l}\text { Cohort size } \geq 30 \\
\& 7 \text { birth year cohorts }\end{array}$}} & \multirow{2}{*}{\multicolumn{4}{|c|}{$\begin{array}{l}\text { Cohort size } \geq 30 \\
\& 14 \text { birth year cohorts }\end{array}$}} \\
\hline & & & & & & & & & & & & & & & & & & & & \\
\hline & coeff & $\begin{array}{l}\text { std } \\
\text { error }\end{array}$ & $\begin{array}{l}\text { adj } \\
R^{2}\end{array}$ & $\mathbf{n}$ & coeff & $\begin{array}{l}\text { std } \\
\text { error }\end{array}$ & $\begin{array}{l}\text { adj } \\
R^{2}\end{array}$ & $\mathrm{n}$ & coeff & $\begin{array}{l}\text { std } \\
\text { error }\end{array}$ & $\begin{array}{l}\text { adj } \\
R^{2}\end{array}$ & $n$ & coeff & $\begin{array}{l}\text { std } \\
\text { error }\end{array}$ & $\begin{array}{l}\text { adj } \\
R^{2}\end{array}$ & $\mathrm{n}$ & coeff & $\begin{array}{l}\text { std } \\
\text { error }\end{array}$ & $\begin{array}{l}\text { adj } \\
R^{2}\end{array}$ & $\mathrm{n}$ \\
\hline \multicolumn{21}{|l|}{ lagged one year: } \\
\hline gini net & $0.0097^{* * *}$ & $(0.0036)$ & 0.180 & 2657 & $0.0140^{* * *}$ & $(0.0041)$ & 0.216 & 2211 & $0.0083^{* *}$ & $(0.0036)$ & 0.141 & 3037 & $0.0090^{* *}$ & $(0.0037)$ & 0.208 & 1963 & $0.0117^{* * *}$ & $(0.0037)$ & 0.180 & 3372 \\
\hline gini market & $0.0060^{* *}$ & $(0.0023)$ & 0.180 & 2657 & $0.0065^{* * *}$ & $(0.0025)$ & 0.213 & 2211 & $0.0074^{* * *}$ & $(0.0022)$ & 0.144 & 3037 & $0.0071^{* * *}$ & $(0.0025)$ & 0.211 & 1963 & $0.0066^{* * *}$ & $(0.0023)$ & 0.180 & 3372 \\
\hline top $1 \%$ income share & $0.0082^{* *}$ & $(0.0037)$ & 0.179 & 2657 & $0.0097^{* *}$ & $(0.0041)$ & 0.213 & 2211 & 0.0037 & $(0.0044)$ & 0.139 & 3037 & $0.0065^{*}$ & $(0.0039)$ & 0.206 & 1963 & $0.0083^{* *}$ & $(0.0036)$ & 0.178 & 3372 \\
\hline $\begin{array}{l}\text { social protection expend, } \\
\% \text { GDP }\end{array}$ & $-0.0111^{* *}$ & $(0.0047)$ & 0.161 & 2348 & $-0.0148^{* * *}$ & $(0.0049)$ & 0.204 & 1957 & $-0.0082^{*}$ & $(0.0045)$ & 0.135 & 2677 & $-0.0103^{*}$ & $(0.0054)$ & 0.187 & 1736 & $-0.0111^{* *}$ & $(0.0044)$ & 0.165 & 2979 \\
\hline \multicolumn{21}{|l|}{ lagged two years: } \\
\hline gini net & $0.0071^{* *}$ & $(0.0033)$ & 0.183 & 2657 & $0.0108^{* * *}$ & $(0.0036)$ & 0.218 & 2211 & 0.0052 & $(0.0032)$ & 0.143 & 3037 & $0.0058^{*}$ & $(0.0033)$ & 0.209 & 1963 & $0.0078^{* *}$ & $(0.0033)$ & 0.182 & 3372 \\
\hline gini market & $0.0033^{*}$ & $(0.0018)$ & 0.182 & 2657 & $0.0035^{*}$ & (0.0019) & 0.215 & 2211 & $0.0035^{* *}$ & $(0.0017)$ & 0.143 & 3037 & $0.0036^{*}$ & (0.0019) & 0.210 & 1963 & $0.0032^{*}$ & $(0.0018)$ & 0.181 & 3372 \\
\hline top $1 \%$ income share & $0.0196^{* * *}$ & $(0.0052)$ & 0.191 & 2657 & $0.0207^{* * *}$ & $(0.0056)$ & 0.225 & 2211 & $0.0124 * *$ & $(0.0061)$ & 0.145 & 3037 & $0.0172^{* * *}$ & $(0.0058)$ & 0.216 & 1963 & $0.0192^{* * *}$ & $(0.0049)$ & 0.188 & 3372 \\
\hline $\begin{array}{l}\text { social protection expend, } \\
\% \text { GDP }\end{array}$ & -0.0049 & $(0.0045)$ & 0.157 & 2329 & -0.0074 & $(0.0047)$ & 0.197 & 1942 & -0.0021 & $(0.0046)$ & 0.135 & 2657 & -0.0037 & $(0.0050)$ & 0.183 & 1722 & -0.0044 & $(0.0041)$ & 0.161 & 2954 \\
\hline \multicolumn{21}{|l|}{1 year lag $\times 2$ year lag: } \\
\hline gini net & $0.0088^{* *}$ & $(0.0035)$ & 0.181 & 2657 & $0.0131^{* * *}$ & $(0.0040)$ & 0.217 & 2211 & $0.0070^{* *}$ & $(0.0035)$ & 0.142 & 3037 & $0.0077^{* *}$ & $(0.0035)$ & 0.208 & 1963 & $0.0102^{* * *}$ & $(0.0035)$ & 0.181 & 3372 \\
\hline gini market & $0.0047^{* *}$ & $(0.0021)$ & 0.181 & 2657 & $0.0051^{* *}$ & $(0.0022)$ & 0.214 & 2211 & $0.0055^{* * *}$ & $(0.0020)$ & 0.143 & 3037 & $0.0053^{* *}$ & $(0.0023)$ & 0.210 & 1963 & $0.0049^{* *}$ & $(0.0021)$ & 0.180 & 3372 \\
\hline top $1 \%$ income share & $0.0137^{* * *}$ & $(0.0046)$ & 0.184 & 2657 & $0.0151^{* * *}$ & $(0.0051)$ & 0.218 & 2211 & 0.0074 & $(0.0055)$ & 0.142 & 3037 & $0.0116^{* *}$ & $(0.0050)$ & 0.210 & 1963 & $0.0135^{* * *}$ & $(0.0045)$ & 0.183 & 3372 \\
\hline social protection expend, & $-0.0091^{*}$ & $(0.0050)$ & 0.159 & 2348 & $-0.0125^{* *}$ & $(0.0052)$ & 0.201 & 1957 & -0.0056 & $(0.0049)$ & 0.134 & 2677 & -0.0080 & $(0.0057)$ & 0.185 & 1736 & $-0.0087^{*}$ & $(0.0045)$ & 0.163 & 2979 \\
\hline
\end{tabular}
$\%$ GDP

${ }^{* * *} p<0.01,{ }^{* *} p<0.05,{ }^{*} p<0.1$. Standard errors are robust and clustered by country and cohort. Each row corresponds to a different regression and only reports the corresponding income inequality coefficient. Each regression includes the same covariates as in Table 5, and year dummies. In the first panel, inequality measures are lagged one year with respect to the ESS wave as in previous specifications. In the middle panel, inequality measures are lagged two years. In the bottom panel, the inequality measures are the averages of the one and two year lags. 


\section{Conclusions}

This paper has shown that income inequality of the country matters for preferences for redistribution when one focusses on changes over time. These results arise from fixed effects estimators applied to pseudo panels for the period 20022012 in 34 European countries. The findings are robust to different measures of income inequality and specifications with different sizes and numbers of synthetic panels. It is shown that increases in pre-tax and transfer income inequality over time raise the demand for redistribution, which is in line with the predictions of early political economy models (Meltzer and Richard 1981) that have not found much empirical support. Income inequality measured with disposable income and the top $1 \%$ income share also positively affects the demand for redistribution. Looking at the evolution of the top $1 \%$ or further concentration shares of income have become increasingly important in the recent empirical literature about inequality, and therefore this study contributes to the understanding of the effects of income concentration on the demand for redistribution. Another important result is that the actual level of redistribution implemented in the country, measured with public expenditures in social protection expenditures, reduces the demand for redistribution. This helps to explain why some Nordic countries exhibit a rather low support for redistribution. In sum, at least in Europe and being mindful of the short length of the period of analysis, one can observe that increasing income inequality leads to more individual support for redistribution.

\section{Endnotes}

${ }^{1}$ Georgiadis and Manning (2012); Pittau et al. (2013); Kerr (2014), Alesina and Giuliano (2011); Alesina and La Ferrara (2005); Alesina and Fuchs-Schundeln (2007); Luttmer and Singhal (2011); Guillaud (2013); Corneo and Grüner (2002); Fong (2001); Yamamura (2012).

${ }^{2}$ The social class position is based on ISCO88 occupational codes, which is only observed for $74 \%$ of the ESS 2002-2012 sample.

${ }^{3}$ Jaeger (2013) (see Appendix's Table 1) uses the following databases to gather information for Gini indexes for the years 2002-2010: World Inequality Database, Wikipedia, http://www.nationmaster.com, http://www.indexmundi.com, Eurostat, World Bank Databank and CIA World Factbook. In addition, 22 country-year points of a total of 125 are allocated Gini indexes corresponding to another year.

${ }^{4}$ The ESS includes a question that indicates which range of total household income the individual belongs to. However, there are two problems in using this question across all waves. There are 12 ranges in waves 2002-2006, and 10 in waves 2008-2012. Furthermore, there is a high percentage of individuals that do not answer the income question of the survey (23\% of the full sample).

${ }^{5}$ The SWIID dataset is built with the United Nations University's World Income Inequality Database (WIID), the Luxembourg Income Study dataset (LIS), the World Top Incomes Database and other country specific data on incomes. This employs a custom missing-data algorithm to standardised the WIID data by using the LIS data as the standard. For more details see Solt (2009).

${ }^{6}$ The oldest birth cohort is $1920-1926$, and the youngest is 1983-1989. 
${ }^{7}$ For more about the asymptotic properties and conditions of pseudo panel estimators, see Verbeek (2008), Verbeek and Vella (2005), Collado (1997) and Moffit (1993).

${ }^{8} \mathrm{GDP}$ per capita is not included in the regression as this is collinear with the social protection expenditures-GDP ratio.

${ }^{9}$ In both datasets, the minimum size of the cells is 30 respondents. The average cell size of the dataset of 7 and 14 birth cohorts is 113 and 62, respectively.

\section{Competing interests}

The IZA Journal of European Labor Studies is committed to the IZA Guiding Principles of Research Integrity. The author declares that he has observed these principles.

\section{Acknowledgements}

I would like to thank the comments and suggestions made by Brian Nolan, Koen Decancq, an anonymous referee and conferences and seminar participants at the University of Antwerp, EPCS meeting at the University of Cambridge, University of Luxembourg, ZEW-Mannheim and Irish Economic Association meeting. The author alone is responsible for the analysis carried on in this study.

Responsible editor: Sara de la Rica

Received: 9 March 2015 Accepted: 30 March 2015

Published online: 10 July 2015

\section{References}

Alesina A, Angeletos GM (2005) Fairness and redistribution. Am Econ Rev 95(4):960-80

Alesina A, Fuchs-Schundeln N (2007) Good Bye Lenin (or not?). The Effect of Communism on People's Preferences. Am Econ Rev 97(4):1507-1528

Alesina A, Giuliano P (2011) Preferences For Redistribution. In Handbook Of Social Economics. Benhabib J, Bisin A, Jackson MO (Eds). North Holland. 93-132

Alesina A, La Ferrara E (2005) Preferences for redistribution in the land of opportunities. J Public Econ 89:897-931

Alesina A, Di Tella R, MacCulloch R (2004) Inequality and Happiness: Are Europeans and Americans Different? J Public Econ 88:2009-2042

Atkinson AB, Piketty T, Saez E (2011) Top Incomes in the Long Run of History. J Econ Lit 49(1):3-71

Barr A, Burns J, Miller L, Shaw I (2015) Economic status and acknowledgement of earned entitlement. Journal of Economic Behavior and Organization. doi: 10.1016/j.jebo.2015.02.012

Benabou R, Ok EA (2001) Social mobility and the demand for redistribution: the POUM hypothesis. Q J Econ 116:447-487

Berigan N, Irwin K (2011) Culture, Cooperation, and the General Welfare". Soc Psychol Q 74(4):341-360

Collado D (1997) Estimating Dynamic Models from Time Series of Independent Cross Sections. J Econ 82:37-62

Corneo G, Grüner HP (2002) Individual preferences for political redistribution. J Public Econ 83:83-107

Cruces G, Perez-Truglia R, Tetaz M (2013) Biased perceptions of income distribution and preferences for redistribution: evidence from a survey experiment. J Public Econ 98:100-112

Deaton A (1985) Panel Data from Times Series of Cross-Sections. J Econ 30:109-126

Fong C (2001) Social preferences, self-interest, and the demand for redistribution. J Public Econ 82(2):225-246

Georgiadis A, Manning A (2012) Spend it like Beckham? Inequality and redistribution in the UK, 1983-2004. Public Choice 151:537-563

Guillaud E (2013) Preferences for redistribution: an empirical analysis over 33 countries. J Econ Inequal 11(1):57-78 Jaeger MM (2013) The effect of macroeconomic and social conditions on the demand for redistribution a pseudo panel approach. Journal of European Social Policy 23:149-163

Karabarbounis L (2011) One Dollar, One Vote. Econ J 121:621-649

Kerr W (2014) Income Inequality and Social Preferences for Redistribution and Compensation Differentials. J Monet Econ 66:62-78

Kuziemko I, Norton M, Saez E, Stantcheva S (2013) How Elastic are Preferences for Redistribution? Evidence from Randomized Survey Experiments. NBER Working Paper 18865

Lind JT (2005) Why is there so little redistribution? Nordic Journal of Political Economy 31:111-125

Luttmer EFP, Singhal M (2011) Culture, Context and the Taste for Redistribution. American Economic Journal: Economic Policy 3(1):157-179

Meltzer AH, Richard SF (1981) A rational theory of the size of the government. J Polit Econ 89(5):914-27

Milanovic B (2000) The median voter hypothesis, income inequality and income redistribution: an empirical test with the required data. Eur J Polit Econ 16(3):367-410

Milanovic B (2010) Four critiques of the redistribution hypothesis: An assessment. Eur J Polit Econ 26:147-154

Moene KO, Wallerstein M (2001) Inequality, social insurance and redistribution. Am Polit Sci Rev 95:859-874

Moene KO, Wallerstein M (2003) Earnings, inequality and welfare spending: a disaggregated analysis. World Politics 55:485-516

Moffit R (1993) Identification and Estimation of Dynamic Models with a Time Series of Repeated Cross-Sections. J Econ 59:99-124

Perotti R (1996) Democracy, income distribution and growth: what the data says. J Econ Growth 1:149-187

Persson T, Tabellini G (1994) Is inequality harmful for growth?: theory and evidence. Am Econ Rev 84:600-621

Piketty T (1995) Social mobility and redistributive politics. Q J Econ 110(3):551-84 
Pittau MG, Massari R, Zelli R (2013) Hierarchical modelling of disparities in preferences for redistribution. Oxf Bull Econ Stat 75(4):556-584

Rodriguez FC (1999) Does Distributional Skewness Lead to Redistribution? Evidence from the United States. Economics \& Politics 11(2):171-199

Schokkaert E, Truyts T (2014) Preferences for Redistribution and Social Structure. KU Leuven Discussion Paper Series DPS14.01

Shayo M (2009) A Model of Social Identity with an Application to Political Economy: Nation, Class and Redistribution. American Political Science Review 103:147-174

Shelton CA (2007) The size and composition of government expenditure. J Public Econ 91:2230-2260

Solt F (2009) Standardizing the World Income Inequality Database. Soc Sci Q 90(2):231-242, SWIID Version 3.1, December 2011

Tóth, IG, Keller T (2011) Income distributions, inequality perceptions and redistributive claims in European societies. Gini Discussion Paper Number 7

Verbeek M (2008) Pseudo Panels and Repeated Cross-Sections. In: Matyas L, Sevestre P (eds) The Econometrics of Panel Data: Fundamentals and Recent Developments in Theory and Practice. Springer, Berlin

Verbeek M, Vella F (2005) Estimating Dynamic Models from Repeated Cross-Sections. J Econ 127:83-102

Yamamura E (2012) Social capital, household income, and preferences for income redistribution. Eur J Polit Econ 28:498-511

Submit your manuscript to a SpringerOpen ${ }^{\circ}$ journal and benefit from:

- Convenient online submission

- Rigorous peer review

- Immediate publication on acceptance

- Open access: articles freely available online

- High visibility within the field

- Retaining the copyright to your article

Submit your next manuscript at $\boldsymbol{~ s p r i n g e r o p e n . c o m ~}$ 